\title{
The Impact of Pareuchaetes pseudoinsulata (Lepidoptera: Arctiidae), on the Growth Rate of Chromolaena odorata (L.) in Southern Ghana
}

\section{*UYI, OSARIYEKEMWEN UYI ${ }^{1}$; DAVID, DAMAA WILSON² ${ }^{2}$ COSTAS, ZACHARIADES ${ }^{3}$}

\author{
${ }^{I}$ African Regional Postgraduate Programme in Insect Science, University of Ghana, Legon, Ghana \\ ${ }^{2}$ Department of Zoology, University of Ghana, P.O. Box 67 Legon-Accra, Ghana \\ ${ }^{3}$ Weeds Division, Plant Protection Research Institute Private Bag X9059, Pietermaritzburg 3200, South Africa \\ e-mail: senatoruyi2010@yahoo.co.uk
}

\begin{abstract}
The abundance and effectiveness of Pareuchaetes pseudoinsulata Rego Barros (Lepidoptera: Arctiidae) in controlling the Siam weed, Chromolaena odorata (L.) King and Robinson in southern Ghana was assessed in C. odorata infested fields through monthly sampling and monitoring surveys carried out between October 2007 and March 2008. Insect data was collected using line transects of 100 metres long and 100 metres apart and the removal, sweep net and direct count methods were used and data on the impact of feeding damage on the weed was collected by measuring several plant characteristics. The populations of $P$. pseudoinsulata were generally low in all sites investigated, throughout the study period. However, higher numbers of the bio-agent were recorded at site \#1 (Akotokyire, Central Region) compared to the other sites and this was significantly $(\mathrm{P}<0.05)$ different. Populations of $P$. pseudoinsulata reached their highest densities between October and December. The damage caused to C. odorata in the field by $P$. pseudoinsulata was too minimal and insignificant to impact negatively on the weed, thus the damage levels recorded are insufficient to meaningfully affect the growth rate of $C$. odorata.@ JASEM
\end{abstract}

Chromolaena odorata (L.) R.M. King and Robinson (=Eupatorium odoratum L.) also known in Ghana as Akyeampong weed, is the most notorious perennial scrambling weed that has proven to be a significant economic and ecological burden to many tropical and sub tropical-regions of the world and is one of the worst alien invasive plant species. The weed is a perennial scrambling shrub native to the West Indies and central and tropical South America (McFadyen, 1988). The weed was first reported in Ghana in 1969 (Hall et al., 1972) and by 1991, it had colonized twothird of the total land area of the country (Timbilla and Braimah, 1996). C. odorata can grow on many soil types but seems to prefer well drained areas. The weed is common in abandoned or neglected fields, along forest trails, fence rows and roadsides (Holm et al., 1977). In Ghana, its effects on Agriculture, forestry, game and wildlife, animal husbandry and the environment at large have been documented (Timbilla and Braimah, 1996). C. odorata can become a fire risk in areas with pronounced dry season. The weed is also known to harbour some important pest of crops notably Zonocerus variegatus (L.) (Orthoptera: Pyrgomorphidae) and Aphis spiraecola Patch (Homoptera: Aphididae) (Uyi, et al., 2008).

The first biological control programme for $C$. odorata worldwide originated in West Africa, when the leaf feeding moth Pareuchaetes pseudoinsulata Rego Barros and the seed feeding weevil Apion brunneonigrun Beguin-Billecocq were imported, bred and released in Ghana and Nigeria in the early 1970s but neither species established (Cock and Holloway 1982). However, a renewed effort began in 1989 at the Biological Control Unit of the Crop
Research Institute, Kumasi, Ghana in collaboration with the University of Guam, USA. Field releases of P. pseudoinsulata mainly in Ashanti and Central Regions began in 1991 to 1997 (Timbilla and Braimah 2000) (Table 1). Post release survey results indicate that the $P$. pseudoinsulata has since then established and spread into other Regions causing extensive but selective damage to $C$. odorata infestations (Braimah and Timbilla 2002). In most biocontrol programmes, post release studies often focus on the establishment and spread of the bioagent(s) while population studies and effectiveness of the released bio-agents in the field are often not studied. A proper understanding of the effectiveness of $P$. pseudoinsulata on $C$. odorata in Ghana is necessary for the sustainability of the biocontrol effort against the weed. Our objectives were to study the abundance of $P$. pseudoinsulata and the impact of the bioagent on C. odorata in the field. We expect that this study will add to the existing information on the biological control of the Siam weed using $P$. pseudoinsulata in the tropics.

\section{MATERIALS AND METHODS}

This research work was carried out in some selected sites in Central, Eastern and Greater Accra Regions of Ghana between October 2007 and March 2008. The study area represented a portion of the core areas occupied and/or colonized by the Alien weed, $C$. odorata. A total of four (4) sites were selected in three Regions for this study. From the release Region (Central), two sites (site \#1, Akotokyire and site \#2, Assin Dadieso) and from non release Region, one site (site \#3, Okumaning-Kade) where infestations of $C$. odorata harboured persisting 
populations of $P$. pseudoinsulata was selected for evaluation and monthly sampling. The responsible land managers in each instance agreed not to spray or clear the sites throughout the study period. The sites were relatively well protected from fire and were thus unlikely to be burnt. However, bio-control exclusion method as described by Farrell and Lonsdale (1997) was incorporated thereby necessitating the need for another site (site \#4, Amasaman), where the bioagent had not spread to as at October 2007, to be used as a control site.

Study site \#1 was located at the University of Cape Coast Farm, Akotokyire, which comprised a considerably large and dense stand of primarily mature $C$. odorata plants; study site \#2 (a palm plantation at Assin Dadieso) also comprised of a considerably large and dense stand of primarily mature $C$. odorata plants. At both study sites, which are in the Central Region, the climate is moist-semi deciduous forest and coastal savannah vegetation tropical with a mean annual rainfall of $580 \mathrm{~mm}$ and $574 \mathrm{~mm}$ and a mean annual temperature of $27.5^{\circ} \mathrm{C}$ and $28.1^{\circ} \mathrm{C}$ at sites $\# 1$ and $\# 2$, respectively. Study site $\# 3$ at Okumaning-Kade comprised of young $C$. odorata plants while study site \#4 (Amasaman) comprised of matured and dense infestation of $C$. odorata plants. The climate here is tropical with a mean annual rainfall of $575 \mathrm{~mm}$ and $530 \mathrm{~mm}$ and a mean annual temperature of $29.4^{\circ} \mathrm{C}$ and $30.1{ }^{\circ} \mathrm{C}$ at sites \#3 and \#4, respectively. At all the study sites, most of the infestation comprised of $C$. odorata plants between 40 and $253 \mathrm{~cm}$ in height.

At the start of the study, to determine the impact of $P$. pseudoinsulata on C. odorata, a two line transects of 100 metres long and 100 metres apart in C. odorata infested areas was sampled using the systematic and stratified sampling method described by Hammond (1992). Four quadrat of $1 \mathrm{~m}^{2}$ each along each $100 \mathrm{~m}$ transect were randomly sampled for collection of insect and plant data Plant features that were recorded monthly included the numbers of leaves, plant heights (using a tape measure and following the length of the stem and longest apex branch) and the numbers of growth points (branches). Features of the insect population and their impact were also assessed. This included the presence of egg batches and frass, numbers of larvae and adults of $P$. pseudoinsulata. The overall feeding damage per plant was scored in six different categories where: $0=$ no feeding damage; 1 = little defoliation; 2 = light intensity damage; $3=$ medium intensity damage; $4=$ high intensity damage; and $5=$ total leaf defoliation and yellowing of plants. Plants that become too large to practically measure and sample were bent before sampling.

\section{ANALYSIS}

The measurements of plant and insect features at impact assessment sites (sites \#1, \#2, \#3 and \#4) were expressed as means and presented as tables. The abundance of $P$. pseudoinsulata at the four (4) study sites were compared by Mann-Whitney test (Siegel, 1956) using Genstat statistical software. This test is useful when comparing independent random samples from different locations and makes no assumption regarding the frequency distribution of the data (Bhattacharyya and Johnson 1977; Sanders and Smidt, 2000). Correlation and regression analysis were used to determine whether there were relationships between numbers of insects and levels of $C$. odorata damage recorded. The means of damaged and undamaged leaves of $C$. odorata within sites as well as damaged $C$. odorata leaves between studies sites were also compared using MannWhitney test.

\section{RESULTS}

Seasonal abundance of $P$. pseudoinsulata in the field

In all the the sites (sites \#1, \#2, \#3 and \#4) the bioagent was recovered during the late rainy season and early dry season (October-December) but insect number was low during the dry season proper (Tables 2-5). Sites \#1 (Akotokyire) and \#3 (Okumaning-Kade) consistently recorded the bioagent throughout the study period except in February with the insect population peaking in October and November. The situation at sites \#2 (Assin Dadieso) and \#4 (Amasaman) were different as the bio-agent was only recorded between November and January. The number of $P$. pseudoinsulata recovered at site \#1 (Akotokyire) was significantly $(\mathrm{P}<0.05)$ higher compared to sites \#2 and \#4. The numbers of the moth recovered at site \#3 was significantly $(\mathrm{P}<0.05)$ higher when compared with numbers recovered at sites \#2 and \#4 (Table 6). There was however no significant differences between insect numbers recovered at sites \#1 and \#3 as well as between sites $\# 2$ and \#4. 
Table 1: Releases of P. pseudoinsulata in Ghana between 1991 and 1997.

\begin{tabular}{lllcll}
\hline Region & Site name & $\begin{array}{l}\text { Duration } \\
\text { releases/Year(s) } \\
\text { releases were made }\end{array}$ & $\begin{array}{l}\text { of } \\
\text { released (adults) }\end{array}$ & $\begin{array}{l}\text { No. of insects } \\
\text { released (larvae) }\end{array}$ & $\begin{array}{l}\text { Establishment } \\
\text { confirmed? }\end{array}$ \\
\hline Ashanti & Fumesua & 1991 & 1489 & 19800 & Y \\
Ashanti & Fumesua & 1992 & 3985 & 38832 & Y \\
Ashanti & Fumesua & 1993 & 791 & 60624 & Y \\
Ashanti & Nfensi & 1996 & - & 47632 & Y \\
Ashanti & Bekwai & 1996 & 1266 & & Y \\
Ashanti & Abesewa & 1996 & 1485 & 50225 & Y \\
Ashanti & Potrikrom & 1997 & 210 & - & $\mathrm{N}$ \\
\hline Central & Assin Dadieso & 1997 & - & 45000 & $\mathrm{Y}$ \\
\hline
\end{tabular}

Table 2: Mean $( \pm \mathrm{SE})$ monthly numbers of $P$. pseudoinsulata and damage levels on $C$. odorata at study site \#1 (Akotokyire, Central Region)

\begin{tabular}{lllllllll}
\hline Month & $\begin{array}{l}\text { Plants } \\
\text { Sample }\end{array}$ & $\begin{array}{l}\text { Plant height } \\
(\mathrm{cm})\end{array}$ & $\begin{array}{l}\text { Leaves/ } \\
\text { plant }\end{array}$ & $\begin{array}{c}\text { Larvae/ } \\
\text { sample }\end{array}$ & $\begin{array}{l}\text { Adult/ } \\
\text { sample }\end{array}$ & $\begin{array}{l}\text { Damaged } \\
\text { leaves/plant }\end{array}$ & $\begin{array}{l}\text { \% Leaves } \\
\text { damaged }\end{array}$ & Damage rating $^{1}$ \\
\hline October & 8 & $132.5 \pm 10.8$ & $130.5 \pm 10.1$ & $1.0 \pm 0.0$ & $1.2 \pm 0.0$ & $8.0 \pm 1.0$ & 6.1 & $2.2 \pm 0.2$ \\
November & 9 & $187.9 \pm 8.7$ & $139.5 \pm 65$ & $1.4 \pm 0.1$ & $1.6 \pm 0.2$ & $7.7 \pm 0.8$ & 5.8 & $1.8 \pm 0.2$ \\
December & 6 & $218.2 \pm 4.1$ & $296.6 \pm 24.6$ & $1.0 \pm 0.0$ & $1.0 \pm 0.0$ & $10.8 \pm 2.1$ & 3.56 & $1.8 \pm 0.2$ \\
January & 6 & $219.6 \pm 8.1$ & $913.1 \pm 17.0$ & $1.0 \pm 0.0$ & $1.0 \pm 0.0$ & $6.8 \pm 1.5$ & 1.0 & $1.7 \pm 0.2$ \\
February & 6 & $200.0 \pm 14.0$ & $220.2 \pm 23.4$ & 0.0 & 0.0 & $3.4 \pm 0.8$ & 1.5 & $0.7 \pm 0.1$ \\
\hline March & 8 & $232.3 \pm 12.0$ & $313.5 \pm 47.1$ & $1.0 \pm 0.0$ & $0.5 \pm 0.0$ & $3.6 \pm 0.8$ & 1.6 & $1.2 \pm 0.8$ \\
\hline
\end{tabular}

${ }^{1}$ Feeding categories defined in text

Table 3: Mean ( \pm SE) monthly number of $P$. pseudoinsulata and damage levels on $C$. odorata at study site \#2 (Assin Dadieso, Central Region)

\begin{tabular}{lclllllll}
\hline Month & $\begin{array}{l}\text { Plants } \\
\text { Sample }\end{array}$ & $\begin{array}{l}\text { Plant height } \\
\text { (cm) }\end{array}$ & $\begin{array}{l}\text { Leaves/ } \\
\text { plant }\end{array}$ & $\begin{array}{l}\text { Larvae/ } \\
\text { sample }\end{array}$ & $\begin{array}{l}\text { Adult/ } \\
\text { sample }\end{array}$ & $\begin{array}{l}\text { Damaged } \\
\text { leaves/plant }\end{array}$ & $\begin{array}{l}\text { \% Leaves } \\
\text { damaged }\end{array}$ & Damage rating $^{1}$ \\
\hline \hline October & 9 & $134.4 \pm 5.9$ & $95.6 \pm 12.1$ & 0.0 & 0.0 & $1.8 \pm 0.3$ & 1.9 & $0.7 \pm 0.0$ \\
\hline October & 9 & $134.4 \pm 5.9$ & $95.6 \pm 12.1$ & 0.0 & 0.0 & $1.8 \pm 0.3$ & 1.9 & $0.7 \pm 0.0$ \\
November & 9 & $168.1 \pm 6.9$ & $100.1 \pm 12.8$ & $0.5 \pm 0.0$ & 0.0 & $1.9 \pm 0.2$ & 1.9 & $0.6 \pm 0.1$ \\
December & 5 & $214.4 \pm 2.3$ & $221.1 \pm 17.8$ & $0.5 \pm 0.0$ & 0.0 & $2.3 \pm 0.4$ & 1.07 & $0.63 \pm 0.1$ \\
January & 7 & $232.0 \pm 16.0$ & $250.2 \pm 19.5$ & 0.0 & 0.0 & $1.6 \pm 0.3$ & 0.7 & $0.93 \pm 0.0$ \\
February & 6 & $235.3 \pm 38.3$ & $259.2 \pm 57.0$ & 0.0 & 0.0 & $3.3 \pm 1.0$ & 1.3 & $0.5 \pm 0.0$ \\
\hline March & 5 & $253.8 \pm 24.5$ & $311.3 \pm 47.5$ & 0.0 & 0.0 & $3.1 \pm 1.0$ & 1.0 & $1.0 \pm 0.1$ \\
\hline
\end{tabular}

${ }^{1}$ Feeding categories defined in text

Table 4: Mean ( $\pm \mathrm{SE})$ monthly number of $P$. pseudoinsulata and damage levels on $C$. odorata at study site \#3 (Okumaning-Kade, Eastern Region)

\begin{tabular}{lllllllll}
\hline Month & $\begin{array}{l}\text { Plants } \\
\text { Sample }\end{array}$ & $\begin{array}{c}\text { Plant height } \\
(\mathrm{cm})\end{array}$ & $\begin{array}{l}\text { Leaves/ } \\
\text { plant }\end{array}$ & $\begin{array}{c}\text { Larvae/ } \\
\text { sample }\end{array}$ & $\begin{array}{c}\text { Adult/ } \\
\text { sample }\end{array}$ & $\begin{array}{c}\text { Damaged } \\
\text { leaves/plant }\end{array}$ & $\begin{array}{l}\text { \% Leaves } \\
\text { damage }\end{array}$ & Damage rating $^{1}$ \\
\hline October & 7 & $40.5 \pm 2.4$ & $27.5 \pm 3.2$ & $1.0 \pm 0.0$ & $1.3 \pm 0.3$ & $1.2 \pm 0.1$ & 5 & $1.1 \pm 0.1$ \\
November & 7 & $61.9 \pm 1.4$ & $38.5 \pm 4.3$ & $0.4 \pm 0.0$ & $0.6 \pm 0.0$ & $1.3 \pm 0.2$ & 3.4 & $1.0 \pm 0.1$ \\
December & 6 & $160.6 \pm 3.3$ & $140.3 \pm 18.0$ & $1.0 \pm 0.0$ & $0.5 \pm 0.0$ & $5.2 \pm 0.6$ & 3.73 & $1.3 \pm 0.1$ \\
January & 9 & $175.0 \pm 6.0$ & $188.4 \pm 6.6$ & $0.5 \pm 0.0$ & $0.5 \pm 0.0$ & $2.3 \pm 0.4$ & 1.2 & $1.0 \pm 0.0$ \\
February & 8 & $182.0 \pm 19.9$ & $236.0 \pm 30.1$ & 0.0 & 0.0 & $3.0 \pm 0.8$ & 1.3 & $0.6 \pm 0.1$ \\
\hline March & 6 & $198.2 \pm 34.5$ & $289.8 \pm 43.8$ & $1.2 \pm 0.0$ & $1.0 \pm 0.0$ & $4.3 \pm 0.9$ & 1.5 & $1.1 \pm 0.2$ \\
\hline
\end{tabular}

${ }^{1}$ Feeding categories defined in text

Table 5: Mean ( $\pm \mathrm{SE})$ monthly number of $P$. pseudoinsulata and damage levels on $C$. odorata at study site \#4 (Amasaman, Greater Accra Region)

\begin{tabular}{lcccccccc}
\hline $\begin{array}{l}\text { Month } \\
\text { rating }\end{array}$ & Plants & Plant height & Leaves/ & Larvae/ & Adult/ & Damaged & \% Leaves & Damage \\
& Sample & $(\mathrm{cm})$ & plant & sample & sample & leaves/plant & damaged & \\
\hline October & 5 & $134.9 \pm 3.4$ & $105 \pm 8.3$ & 0.0 & 0.0 & $0.6 \pm 0.1$ & 0.5 & $0.5 \pm 0.1$ \\
November & 5 & $135.5 \pm 10.9$ & $41.8 \pm 3.5$ & $0.2 \pm 0.0$ & 0.0 & $3.4 \pm 0.2$ & 2.8 & $1.1 \pm 0.0$ \\
December & 4 & $195.9 \pm 5.0$ & $68.8 \pm 5.0$ & 0.0 & 0.0 & $1.6 \pm 0.3$ & 2.4 & $1.0 \pm 0.0$ \\
January & 6 & $197.3 \pm 19.7$ & $109.8 \pm 8.4$ & $0.5 \pm 0.0$ & 0.0 & $1.0 \pm 0.1$ & 1.0 & $0.9 \pm 0.0$ \\
February & 9 & $210.1 \pm 39.8$ & $232.7 \pm 54.8$ & 0.0 & 0.0 & $3.5 \pm 0.9$ & 1.5 & $0.8 \pm 0.2$ \\
\hline March & 7 & $219.5 \pm 34.7$ & $326.1 \pm 48.8$ & 0.0 & 0.0 & $2.8 \pm 0.5$ & 0.8 & $0.9 \pm 0.0$ \\
\hline
\end{tabular}

${ }^{1}$ Feeding categories defined in text

* Corresponding author: *Uyi, Osariyekemwen Uyi 
Table 6: Comparison of mean numbers of $P$. pseudoinsulata (adults+larvae) recovered per $\mathrm{m}^{2}$ between the study sites

\begin{tabular}{lll}
\hline & \multicolumn{1}{c}{ Site \# } & Mean number of $P$. pseudoinsulata \\
\hline 1 & (Akotoyire) & $1.78 \pm 0.13^{\mathrm{a}}$ \\
2 & (Assin-Dadieso) & $0.16 \pm 0.02^{\mathrm{b}}$ \\
1 & (Akotoyire) & $1.78 \pm 0.13^{\mathrm{a}}$ \\
3 & (Okumaning-Kade) & $1.53 \pm 0.21^{\mathrm{a}}$ \\
1 & (Akotoyire) & $1.78 \pm 0.13^{\mathrm{a}}$ \\
4 & (Amasaman) & $0.15 \pm 0.01^{\mathrm{b}}$ \\
2 & (Assin-Dadieso) & $0.16 \pm 0.02^{\mathrm{a}}$ \\
3 & (Okumaning-Kade) & $1.53 \pm 0.21^{\mathrm{b}}$ \\
2 & (Assin-Dadieso) & $0.16 \pm 0.02^{\mathrm{a}}$ \\
4 & (Amasaman) & $0.15 \pm 0.01^{\mathrm{a}}$ \\
\hline 3 & (Okumaning-Kade) & $1.53 \pm 0.21^{\mathrm{a}}$ \\
4 & (Amasaman) & $0.15 \pm 0.01^{\mathrm{b}}$ \\
\hline \multicolumn{7}{l}{ Means compared by Mann-Whitney U tests; means followed by different letters are significantly different $(\mathrm{P}<0.05)}$.
\end{tabular}

Table 7: Pearson correlation coefficients of the abundance (adults and larvae) of $P$. pseudoinsulata and feeding damage variables of $C$. odorata at the respective study sites

\begin{tabular}{|c|c|c|c|c|}
\hline Damage classification & $\begin{array}{l}\text { Correlation } \\
\text { coefficient } r\end{array}$ & $\begin{array}{l}\text { Coefficient of } \\
\text { determination } \mathrm{R}^{2}\end{array}$ & $\begin{array}{l}\text { Probability } \\
\text { of } r\end{array}$ & Remark \\
\hline \multicolumn{5}{|l|}{ Site \# 1 (Akotoyire) } \\
\hline Damaged leaves & 0.870 & 0.757 & 0.025 & * \\
\hline$\%$ leaves damaged & 0.782 & 0.610 & 0.061 & NS \\
\hline Damage rating & 0.860 & 0.739 & 0.029 & $*$ \\
\hline \multicolumn{5}{|l|}{ Site \# 2 (Assin-Dadieso) } \\
\hline Damaged leaves & -0.251 & 0.063 & 0.627 & NS \\
\hline$\%$ leaves damaged & 0.302 & 0.091 & 0.558 & NS \\
\hline Damage rating & -0.440 & 0.193 & 0.383 & NS \\
\hline \multicolumn{5}{|c|}{ Site \# 3 (Okumaning-Kade) } \\
\hline Damaged leaves & 0.162 & 0.025 & 0.763 & NS \\
\hline$\%$ leaves damaged & 0.374 & 0.139 & 0.474 & NS \\
\hline Damage rating & -0.031 & 0.001 & 0.953 & NS \\
\hline \multicolumn{5}{|l|}{ Site \# 4 (Amasaman) } \\
\hline Damaged leaves & -0.251 & 0.063 & 0.627 & NS \\
\hline$\%$ leaves damaged & 0.011 & 0.000 & 0.984 & NS \\
\hline Damage rating & 0.301 & 0.090 & 0.562 & NS \\
\hline
\end{tabular}

*Significant at $\mathrm{P}<0.05$

NS, not significant

The Impact of $P$. pseudoinsulata on the growth rate of $C$. odorata

Feeding by $P$. pseudoinsulata did not appear to influence the growth of $C$. odorata plants to any extent (Tables 2-5). The Pearson correlation coefficients of the abundance (adults and larvae) of $P$. pseudoinsulata and feeding damage variables of $C$. odorata at the respective study sites are shown in Table 7.

Site \#1 (Akotokyire) recorded the highest number of damaged $C$. odorata leaves per plant in December while percentage of leaves damaged and damage rating was higher during the October and November surveys. The numbers of undamaged $C$. odorata leaves at site $\# 1(\bar{x} \pm \mathrm{SE}=274.5 \pm 32, \mathrm{n}=144)$ was significantly $(\mathrm{P}<0.001$, Mann-Whitney $\mathrm{U}$ test) higher than the damaged leaves $(\bar{x} \pm \mathrm{SE}=6.80 \pm 0.57, \mathrm{n}=$ 144). There was a significant positive correlation $\left(\mathrm{R}^{2}=0.757 ; \quad \mathrm{P}<0.025\right)$ between insect abundance (larvae and adults combined) and damaged $C$. odorata leaves. There was also a significant positive correlation $\left(\mathrm{R}^{2}=0.739 ; \mathrm{P}=<0.029\right)$ between insect abundance and damage rating. Insect abundance and percentage of leaves damage was also positively correlated $\left(\mathrm{R}^{2}=0.61 ; \mathrm{P}<0.061\right)$ but was however not significant.

Sites \#2 (Assin Dadieso) recorded the highest number of damaged leaves per plant in February, while percentage of leaves damaged and damage rating was highest in October and March. There was a significant difference $(\mathrm{P}<0.001)$ between damaged $(\bar{x}$ $\pm \mathrm{SE}=3.0 \pm 0.39, \mathrm{n}=144)$ and undamaged $(\bar{x} \pm \mathrm{SE}$ $=261.1 \pm 39, \mathrm{n}=144)$ C. odorata plants. There was a weak relationship between insect abundance and damaged leaves $\left(R^{2}=0.065\right)$, percentage of leaves damaged $\left(\mathrm{R}^{2}=0.091\right)$ as well as damage rating $\left(\mathrm{R}^{2}=0.19\right)$. However these relationships were too weak to be significant. Okumaning-Kade (site \#3) experienced the highest number of damaged leaves per plant as well as damage rating in December, while percentage of leaves damaged was highest in October. As expected, the numbers of undamaged

* Corresponding author: *Uyi, Osariyekemwen Uyi 
leaves $(\bar{x} \pm \mathrm{SE}=128.7 \pm 14, \mathrm{n}=144)$ was significantly $(\mathrm{P}<0.001)$ higher than the damaged $C$. odorata leaves $(\bar{x} \pm \mathrm{SE}=2.6 \pm 0.28, \mathrm{n}=144)$. Correlation analysis demonstrated weak relationships between insect abundance and damaged leaves, percentage leaves damaged as well as damage ratings. At site $\# 4$, the numbers of damaged leaves, percentage of leaves damaged and damage rating reached its peak in November. As usual the number of undamaged leaves $(\bar{x} \pm \mathrm{SE}=139.6 \pm 16, \mathrm{n}=144)$ was significantly $(\mathrm{P}<0.001)$ higher compared to the damaged $C$. odorata leaves $(\bar{x} \pm \mathrm{SE}=1.7 \pm 0.25, \mathrm{n}=$ 144). It is also important to note that correlation analysis demonstrated weak relationships between insect abundance and other feeding damage variables.

\section{Comparison of damaged leaves between sites}

The numbers of damaged $C$. odorata leaves recorded at sites \#1, \#2, \#3 and \#4 comparatively, were significantly different $(\mathrm{P}<0.05)$. Results of the $\mathrm{U}$ test showed that site $\# 1(\bar{x} \pm \mathrm{SE}=6.77 \pm 0.57, \mathrm{n}=144)$ had significantly higher $(\mathrm{P}<0.05)$ number of damaged leaves compared to sites \#2 $(\bar{x} \pm \mathrm{SE}=2.90 \pm 0.39, \mathrm{n}$ $=144), \# 3(\bar{x} \pm \mathrm{SE}=2.59 \pm 0.28, \mathrm{n}=144)$ and $\# 4(\bar{x}$ $\pm \mathrm{SE}=1.64 \pm 0.25, \mathrm{n}=144)$ whereas the number of damaged leaves at sites \#2 and \#3 was not significantly different $(\mathrm{P}=0.07)$. The number of damaged leaves at sites \#2 and \#4 was significantly different $(\mathrm{P}<0.007)$, and the number of damaged leaves at site \#3 was significantly $(\mathrm{P}<0.014)$ higher compared to site \#4.

\section{DISCUSSION}

\section{Abundance of $P$. pseudoinsulata at the impact sites}

The abundance and distribution of the bio-agent at the various sites where the impact of $P$. pseudoinsulata on $C$. odorata was assessed was possibly influenced by seasonality, temperature and relative humidity with increase in the population of the moth during the late rainy season period while their population decreased as the intense dry season approaches. In all the sites where this study was carried out, the population of $P$. pseudoinsulata was highest in November. Population of the insect always increased dramatically between April and November (Timbilla and Braimah, 1998) and decrease to near absence during the intense dry season,(Timbilla and Braimah, 2000) noting a gradual decline of their populations in December (Timbilla and Braimah, 1998). Higher numbers of the bio-agent were recorded at site $\# 1$ compared to the other three sites except site \#3 and this was significantly $(\mathrm{P}<0.05)$ different. The population of the bio-agent recorded at site \#3 (Okumaning-Kade) was significantly higher than numbers recorded at site \#2 (Assin Dadieso) and site \#4 (Amasaman). The low numbers of the moth recorded at Assin Dadieso may be due to the migration of the bio-agent to other areas probably in their quest for suitable ecoclimatic conditions. The populations of the moth at site \#2 (Assin Dadieso) and site \#4 (Amasaman) were not significantly different.

\section{Feeding damage and response of $C$. odorata to feeding by $P$. Pseudoinsulata in the Field}

Little insect damage (negligible) caused to $C$. odorata plants was observed at all four sites and the insect population did not inflict extensive levels of damage on the target weed population as evident in the percentage of leaf damage, height, number of damaged leaves and damage rating. Even when and where the insect abundance was at its highest, the mean levels of feeding damage comprised mostly of light intensity leave defoliation. Timbilla and Braimah (2000), reported P. pseudoinsulata to have established and spread to wider areas causing extensive damage to the weed and resulting in the death of the plants. The reports of these authors contradict the findings of this research. However, Day and Bofeng (2007) reported minimal damage to C. odorata in Papua New Guinea. Higher numbers of damaged leaves, percentage of damage leaves and damage rating at all sites coincided with the period where $P$. pseudoinsulata were present in high numbers. This confirms the findings of Marutani and Muniappan (1991), who observed a similar trend in Guam. The numbers of the undamaged $C$. odorata leaves recorded at all sites were significantly $(\mathrm{P}<0.001)$ higher than the damaged leaves. This is probably due to the low numbers of insects present in the field at the time of this survey. Day and Bofeng (2007) noted that the insect numbers are generally low and there is minimal damage to C. odorata plants for much of the year, especially during the dry season.

This study shows a highly significant positive correlation between $P$. pseudoinsulata abundance and damage $C$. odorata leaves per square metre. Thus as the population of $P$. pseudoinsulata increases, the number of damaged leaves also increases. There was also a strong and significant relationship between $P$. pseudoinsulata population and damage rating as well as percentage number of damaged leaves, suggesting that higher number of $P$. pseudoinsulata will cause higher leaf damage to $C$. odorata plants. This was only observed at site \#1 (Akotokyie, Central Region), while sites \#2, \#3 and \#4 had very weak relationships between insect abundance and the damage variables investigated. This suggests that in areas where the insects are in large numbers, the insects can cause appreciable damage to the plants. Day and Bofeng (2007) in Papua New Guinea reported that when larval numbers are high after the wet season, $C$.

* Corresponding author: *Uyi, Osariyekemwen Uyi 
odorata plants can become devoid of all leaves and the larvae can be seen feeding on young stems. These authors however concluded that control of $C$. odorata has also been limited to seasonal damage.

The numbers of damaged leaves recorded at all the sites were significantly $(\mathrm{P}<0.05)$ different, with site \#1 (Akotokyire) having significantly higher number of damaged leaves compared to the other sites. The higher number of damaged leaves at site \#1 may be probably due to the fact that site \#1 is nearer to the release site at Assin Dadieso and climatic conditions may also be more favourable. The numbers of damaged leaves at sites \#2 (Assin Dadieso) and \#3 (Okumaning-Kade) were however not significantly different, this may be as a result of the low population of $P$. pseudoinsulata in these sites. Although the bio-agent was released at Assin Dadieso, the insect may have however migrated to other areas where environmental conditions may be more favourable. The significantly $(\mathrm{P}<0.05)$ higher numbers of damaged leaves at site \#2 (Assin Dadieso) compared to site \#4 (Amasaman) suggest that only few numbers of the moth has spread to Amasaman (Greater Accra Region) which is about 256, 315 and 243 kilometres from the various release sites at Fumesua, Bekwai and Assin Dadieso respectively. The same reason can also be given for the significantly $(\mathrm{P}<0.05)$ higher numbers of damaged leaves at site \#3 (Okumaning-Kade) compared to site \#4 at Amasaman. Moreover Okumaning-Kade is nearer to the release sites in Ashanti Region. This study shows that damage at all the sites were not so spectacular, as the plant showed no sign of distress and the damage caused was too negligible to cause the death of $C$. odorata plants. The continuous increase in the height of the $C$. odorata plants also confirms this.

The damage caused to $C$. odorata in the field was too minimal and insignificant to impact negatively on the weed. Despite the damage inflicted by the bio-agent, control of $C$. odorata is still largely dependent on other control measures, hence the biological control programme of $C$. odorata in Ghana cannot be rated as a "success". Considering that, the problem of this weed is too ecologically and economically significant to ignore, an integrated approach is needed for the control and management of the weed in West Africa. In this regard, the introductions of the gall fly Cecidochares connexa (Macquart) (Diptera: Tephritidae) into Ghana (Timbilla et al, 2003) is highly recommended. In conclusion, the introduction of $P$. pseudoinsulata has not caused any significant damage to $C$. odorata in southern Ghana and since no one agent alone can be expected to suppress $C$. odorata infestations, simultaneous introduction if possible, of several candidates causing different types of injury should be attempted.
Acknowledgement: The authors are grateful to the indigenous people and the responsible land owners/managers for their contributions and support. This study was funded by the German Academic Exchange Service (DAAD) through the African Regional Postgraduate Programme in Insect Science (ARPPIS), West Africa Sub-regional Centre, University of Ghana, Legon-Accra, Ghana.

\section{REFERENCES}

Bhattacharyya, G. K. and Johnson, R. A. (1977). Non parametric inference. In: Statistical concepts and methods. John Wiley and Sons. United States. pp 505-549

Braimah and Timbilla (2002). A Decade of successful biological control of Siam weed, Chromolaena odorata in Ghana: Lessons and future plans. In: Zachariades, C., R. Muniappan, and L.W Strathie (eds). Proceedings of the Fifth International Workshop on the Biological Control and Management of Chromolaena odorata, Durban, South Africa, October 2000, ARC-Plant Protection Research Institute (2002), pp. 58-65.

Cock, M. W. J and Holloway, J. D. (1982). The history of, and prospect for the biological control of Chromolaena odorata (Compositae) by Pareuchaetes pseudoinsulata Rego Barros and allies (Lepidoptera, Arctiidae). Bulletin of Entomological Research 72: 193-205.

Day, M. and Bofeng, I. (2007). Biocontrol of Chromolaena odorata in Papua New Guinea. In: Po Yung Lai, Reddy, G. V. P. and R. Muniappan (eds.). Proceedings of the Seventh International Workshop on Biological Control and Management of Chromolaena odorata and Mikania micrantha, 12-13 September, 2006, Taiwan. pp. 53-67.

Farrell, G. and Lonsdale, M. (1997). Measuring the impact of biological control agents on weeds. In: M. Julien and G. White (eds). Biological control of weeds: theory and practical applications. Australia Centre for International Agricultural Research, Canberra, Australia. pp. 105-118.

Hall, J. B., Kumar, R. and Enti, K. A. (1972). The obnoxious weed Eupatorium odoratum (Compositae) in Ghana. Ghana Journal of Agricultural Sciences 5: 75-78.

Hammond, W. N.O. (1992). Survey and sampling Cassava Mealybug and its natural enemies population. In: Markham, R.H, Wodageneh, A., 
Agboola, S. (eds). Biological Control Manual, Volume II: Case Studies of Biological Control in Africa. IITA Biological Control Center for Africa, Cotonou, Republic of Benin. pp. 48-69.

Holm, L. G., Plucknett, D. L. and Pancho, J. V. (1977). The World Worst Weeds: Distribution and Biology. University Press of Hawaii, Honolulu, pp. 212-216.

Marutani, M. and Muniappan, R. (1991). Succession of vegetation after suppression of Chromolaena odorata by Pareuchates pseudoinsulata in Guam. In: Muniappan, R. and Ferrar, P. (eds.) Proceedings of the Second International Workshop on Biological Control of Chromolaena odorata. February 1991. Biotrop Special Publication 44, Bogor, Indonesia. pp. 143-150.

McFadyen, R.E.C. (1988). History and distribution of Chromolaena odorata. In: Muniappan, R. (ed). Proceedings of the First International Workshop on Biological Control of Chromolaena odorata. Feb.-March 1988, Bangkok, Thailand. Agriculture Experimental Station, Guam, pp 712.

Muniappan, R., Sundaramurthy, V. T. and Virktamath, C. A. (1989). Distribution of Chromolaena odorata (Asteraceae) and Bionomics and Utilization of Food by Pareuchaetes psuedoinsulata (Lepidoptera: Arctiidae) in India. In: Delfosses, E.S (ed). Proceedings of the Seventh International Symposium on Biological Control of Weeds, Rome, Italy. pp 401-409.

Sanders, H. D. and Smidt, S. (2000). Statistics, a first course. Sixth edition, McGraw-Hill Higher Education, New York. 664pp.

Siegel, S. (1956). Non parametric statistics for the behavioural sciences. McGraw-Hill, New York. 312pp.
Timbilla, J.A and Braimah, H. (1996). A Survey of the Introduction, Distribution and Spread of Chromolaena odorata in Ghana. In: Prasad, U.K., R. Muniappan, P. Ferrar, J.P. Aeschliman and $\mathrm{H}$. de Foresta (eds), Proceedings of the Third International Workshop on Biological Control and Management of Chromolaena odorata. Abidjan, Cote d 'Ivoire, November 1993. Agricultural Experimental Station, University of Guam, Publication No. 202, pp. 6-18.

Timbilla, J. A. and Braimah, H. (1998). Recent advances in the biological control of Chromolaena odorata and subsequent effect on biodiversity in Ghana. A Paper Presented to the Awards Committee, Best National Agricultural Researcher in Ghana. 37pp.

Timbilla, J. A and Braimah, H. (2000). Establishment, Spread and Impact of Pareuchaetes pseudoinsulata (Lepidoptera: Arctiidae), an Exotic Predator of the Siam Weed, Chromolaena odorata (Asteraceae: Eupatoriae) in Ghana. In: Spencer, N.R. (ed). Proceedings of the Tenth International Symposium on the Biological Control of Weeds, Montana, July, Montana State University, Bozeman, USA, pp. 105-111.

Timbilla, J. A., Zachariades, C. and Braimah, H. (2003). Biological control and management of the alien invasive shrub, Chromolaena odorata in Africa. In: Neuenschwander, P., Borgemeister, C., Langewald, J. (eds). Biological Control in IPM Systems in Africa. CAB International, London. pp. 145-160.

Uyi, O. U, Aisagbonhi, C. I., and Egbon, I. N. (2008). Occurrence and distribution of Aphis spiraecola (Patch) on Chromolaena odorata (L.) in Nigeria: Implication for pest outbreak and the need to control the weed. Chromolaena Newsletter 17: 4-7.

* Corresponding author: *Uyi, Osariyekemwen Uyi 